\title{
Performance of proposed earth-Tank Heat Exchanger: A Computational Study
}

\author{
Ajoy Debbarma \\ ${ }^{1}$ M.Tech Scholar, Thermal Engineering, N.I.T Silchar, Assam
}

\begin{abstract}
Research activities are ongoing to develop Earth-Air Heat Exchanger (EAHX) with the purpose to achieve a high efficiency and to improve their economical competitiveness. However, there is still a big deficiency in understanding and prediction of soil temperature in various depths on earth. In this paper, tank were proposed in the conventional model and has been investigated using the computational fluid dynamics (CFD) code FLUENT to provide basic knowledge of the Air flow behaviour and to gather the first experience in the application of CFD codes to heat transfer in Earth-Air Heat Exchanger (EAHX). .An Earth-Air Heat Exchanger (EAHX) is a simple subterranean cooling system that utilizes the stable soil temperature that is cooler than ambient temperature in summer. A single pass earth-tube heat exchanger (ETHE) was performed to study its performance in cooling. ETHE is made of $0.5 \mathrm{~m}$ long $10 \mathrm{~cm}$ diameter ms pipe at inlet and $3.5 \mathrm{~m}$ long outlet tank with both wall thickness of $3 \mathrm{~mm}$. A $1 \mathrm{~m}^{2}$ area tank is buried at $3 \mathrm{~m}$ deep below surface. Ambient air is supply. Air at $11 \mathrm{~m} / \mathrm{s}$. Computational cooling tests was carried out using k-epsilon standard and RNG model. In this paper an earth-to air heat exchanger was considered based on summer cooling system. Numerical model shows ETHE was able to reduce the temperature of hot ambient air by as much as $9.8^{\circ} \mathrm{C}$ in May. This natural geothermal based system can decrease heating loads and significantly reduce the room air temperature during summer seasons.
\end{abstract}

Keywords - Earth Tank Heat Exchanger, Earth-air, cooling potential.

\section{INTRODUCTION}

Earth-to-air heat exchangers, also called ground tube (or tank as author proposed in this paper) heat exchangers, are an interesting technique to reduce energy consumption in a building. Several papers have been published in which a design method is described. As the need for energy-efficient building designs increases, the use of passive cooling and renewable resources also increases. One way to reduce the use of energy in the cooling of ventilation air is to pre-cool the air in the summer using an earth-air heat exchanger (EAHE) also known as an earth-tank. In an EAHE, ventilation air is drawn into the building through a system of tank located in the soil near or beneath the building. EAHEs are not a new technology; indeed, the concept dates back at least to the $1^{\text {st }}$ century BC in the Middle East (Oleson, 2008).The EAHE concept is quite simple: a tank is buried in the soil as shown in Figure 1. The soil will be at a temperature cooler than the outside air in summer.

Cooling needs of dwelling houses can be significantly reduced by utilization of the stored energy derived from the ground, So-called earth heat exchanger are becoming more and more popular systems that are applied in the energy saving buildings. Earth to air heat exchangers (EAHE) mostly consists of metal, concrete or plastic buried pipes, inlet tower, registers, condensation management protect device, filter and fan. In this paper heat exchanger pipe are replace by small tank so be called Earth-Tank Heat Exchanger. Earth-Heat Exchanger is a device that enables transfer of heat from ambient air to deeper layers of soil. Since the early exploration of its use in cooling commercial livestock buildings (Scott et al 1965) there has been considerable increase in its application.

\section{CONCEPT EARTH-AIR HEAT EXCHANGER DESCRIPTIONS}

The principle of earth to air underground heat exchangers is very simple. The conceptual ETHE is tank is buried in the soil as shown in Figure 1. The system uses the seasonal thermal storage ability of the soil, which has a temperature delay compared to the outdoor temperature. This temperature difference between the outdoor temperature and the soil temperature enables a cooling effect of the hot summer air. The utilization of the stored cold in the ground with the means of an underground heat exchanger depends on the ground composition and the local microclimate. The solar global radiation heats the surface of the earth and the heat absorbed depends on the surface character (cover, construction, etc.). The temperature of the ground in the different layers depends on the climate (outdoor temperature, wind, precipitation, etc.) and the composition of the earth (heat conductivity, specific heat and density). Since the underground heat exchanger operates close to the earth surface, there is no influence from geothermal parameters. The underground heat exchanger should be placed on 
ground water level. The ground temperature is influenced if the heat exchanger is placed in areas with dense construction area or under a building. The heat exchanger can only be applied in climates with big temperature differences between summer and winter and between day and night.

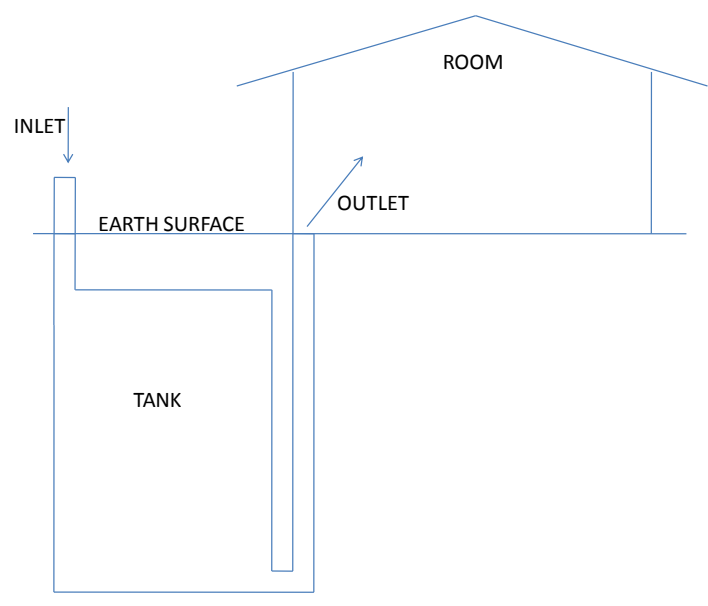

Fig.1. Conceptual Earth-Tank Heat Exchanger

In order to specify a workable solution designer of ETHE systems should evaluate:

a. Location: If the system is predominantly cooling you will want the collector in a permanently shaded area near a lake or river. If the system is predominately heating it should be located in a sunny area without some aquifer competing to steal away the heat.

b. Depth of pipe (temperature): Available shortwave radiation on the collector surface is directly related to the mode the system favors' most with consideration for the depth of pipe and can typically be between $1.5 \mathrm{~m}$ to $3 \mathrm{~m}$. A system that is designed predominately for cooling in an area without shading will need the pipes buried deeper than a system designed for heating in the same locale.

c. Soil conductivity (heat transfer): Dry sand is the worst thing one would want in the process of conducting heat to and from buried ducts. Dense, wet and conductive (can you say moist compacted clay) is the trick.

d. Duct material and tube connections: Options include concrete, metal, plastics - with or without conductive fins or antimicrobial agents. The ducts cannot sag under loading. The connections have to be robust and of the highest quality as they and the ducts have to deal with ground moisture and soil gases. They must be of the most conductive material for the lowest cost with the least air flow resistance but offer the best characteristics against corrosion.

e. Temperatures, flow, velocity, diameter, friction, length, layout and drainage (the thermal to hydraulic part of the calculation): According to application engineers, velocities between $6 \mathrm{~m} / \mathrm{s}$ to $10 \mathrm{~m} / \mathrm{s}$ are typical. This means the diameter has to be picked based on flows and friction losses. To optimize designs based on the thermal and pressure requirements, using several shorter lengths in parallel in a reverse return arrangement can in some cases be better than a single longer serpentine loop or it may be more suitable to use a loop that follows the perimeter of the buildings foundation.

f. Air entering the ground duct and the HVAC system will need to be conditioned: This means it has to be suitable for inhalation by the occupants through the decontamination of particulates, moisture, odours, gases and biological concerns.

g. Energy analysis: The designer will need to evaluate the capital and operating costs of the system, including the electricity to run the fan and decontamination equipment to assure the energy used is lower than the cooling or heating power offered by the system.

h. Building science issues: Depending on the type of system there could be issues with infiltration and short circuiting of the ground exchanger. It is necessary that both building and ducts are sealed tightly to prevent differential pressures across and within the home from interfering with the required differential pressures in the ETHE.

\section{COMPUTATIONAL STUDY OF EARTH-TANK HEAT EXCHANGER}

ETHE consists of a $0.5 \mathrm{~m}$ long $10 \mathrm{~cm}$ diameter $\mathrm{ms}$ pipe at inlet and $3.5 \mathrm{~m}$ long outlet tank with both wall thickness of $3 \mathrm{~mm}$. A $1 \mathrm{~m}^{2}$ area, $3 \mathrm{~m}$ deep was first excavated by a bucket excavator. The inlet and outlet of the ETHE rise $0.5 \mathrm{~m}$ above ground. Inlet is connected to the delivery end of blower and outlet is open to atmosphere (desired room). 


\section{Cooling Mode Tests}

The tank air temperature at the upper, middle and bottom, and soil temperature at 3-meter depth, the ambient temperature started with $31.3^{\circ} \mathrm{C}$ at $10.00 \mathrm{AM}$ and rose to a maximum of $35.8^{\circ} \mathrm{C}$ at 2 PM. The temperature of air at outlet was $28^{\circ} \mathrm{C}$. The outlet temperature was just above the basic soil temperature $(26.60 \mathrm{C})$ at $3 \mathrm{~m}$ depth, suggesting that the tank was exchanging heat quite effectively. As can be seen from the table most of the cooling occurred in the bottom of the tank. The volume flow rate of air was $0.0863 \mathrm{~m} 3 / \mathrm{s}$ and mass flow rate $0.0975 \mathrm{~kg} / \mathrm{s}$.

Coefficient of performance is one of the measures of heat exchanger efficiency. It is defined as (ASHRAE 1985)

$$
\begin{aligned}
& \mathrm{COP}=\frac{\dot{Q}_{\text {out }}}{\dot{\mathrm{W}}_{\text {in }}} \\
& \dot{Q}_{\text {out }}=\dot{m}_{a} C_{p}\left(T_{i}-T_{o}\right)
\end{aligned}
$$

$C_{p} \quad$ Specific heat of air $\left(\mathrm{J} / \mathrm{kg}^{\circ} \mathrm{C}\right)$

$\dot{Q}_{\text {out }} \quad$ Rate of energy input into the heat exchanger (energy used by blower)

$\dot{W}_{i n} \quad$ Rate at which heat is exchanged between hot air and cooler soil

$m_{a} \quad$ Mass flow rate of air $(\mathrm{kg} / \mathrm{s})$

$T_{i} \quad$ Temperature of air entering the tube $\left({ }^{\circ} \mathrm{C}\right)$

$T_{o} \quad$ Temperature of air at the outlet (oC)

$T_{i}$ and $T_{o}$ are both treated as bulk temperatures. This is realistic, pipe diameter being only $10 \mathrm{~cm}$.

Energy input into the heat exchanger is just the energy used by the blower $(300 \mathrm{w})$. In the first hour of operation (10.00 - $11.00 \mathrm{AM}$ ) the ambient air temperature raised from31.3oC to 33.3oC. The mean of this works out to 32.3oC. We shall assume this to be, Ti, during this first hour. Properties of air used in computation relate to temperature of $35^{\circ} \mathrm{C}$.

$$
\begin{aligned}
\mathrm{COP} & =[\{0.0975 \times 1007 \times(32.3-28)\} / 300] \\
& =1.408
\end{aligned}
$$

Model wise, values of COP are shown in Table-1. COP value was 1.408 at $32^{\circ}$ C.Baxter presented detailed analysis of ETHE performance during three weekly periods --first week of June, third week of July and last week of August. These represent periods where high ambient temperatures prevail and cooling is greatly needed. During these periods the value of COP in the hours of high energy exchanges (day time when ambient temperatures were high) ranged from 4.37 to 6.31 . The mean hourly values for the entire period of test ranged from 1.4 to 2.69 . The maximum ambient temperature varied from $33.9 \mathrm{oC}$ to $35.6^{\circ} \mathrm{C}$.

Table 1: Air Temperature inside ETHE and Soil Temperature

\begin{tabular}{|c|c|c|c|c|}
\hline Model & Ta & Ts & To & COP \\
\hline Standard -epsilon & 32.3 & 26.6 & 28 & 1.408 \\
\hline RNG -epsilon & 32.3 & 26.6 & 29 & 1.080 \\
\hline RNG -epsilon & 41.4 & 26.6 & 32 & 3.077 \\
\hline RNG -epsilon & 40.8 & 26.6 & 31 & 3.208 \\
\hline
\end{tabular}

Table 2: Summary of Cooling Test Results

\begin{tabular}{|c|c|c|c|}
\hline Month & $\begin{array}{c}\text { Ambient Temperature } \\
\text { At } 14 \text { hours }(\stackrel{\circ}{\mathrm{C}})\end{array}$ & $\begin{array}{l}\text { Basic Soil Temperature } \\
\text { Ts }\left({ }^{\circ} \mathrm{C}\right)\end{array}$ & $\begin{array}{c}\text { Outlet Temperature } \\
\text { At 14 hours }\left({ }^{\circ} \mathrm{C}\right)\end{array}$ \\
\hline April & 41.4 & 26.6 & 32 \\
\hline May & 40.8 & 26.6 & 31 \\
\hline
\end{tabular}



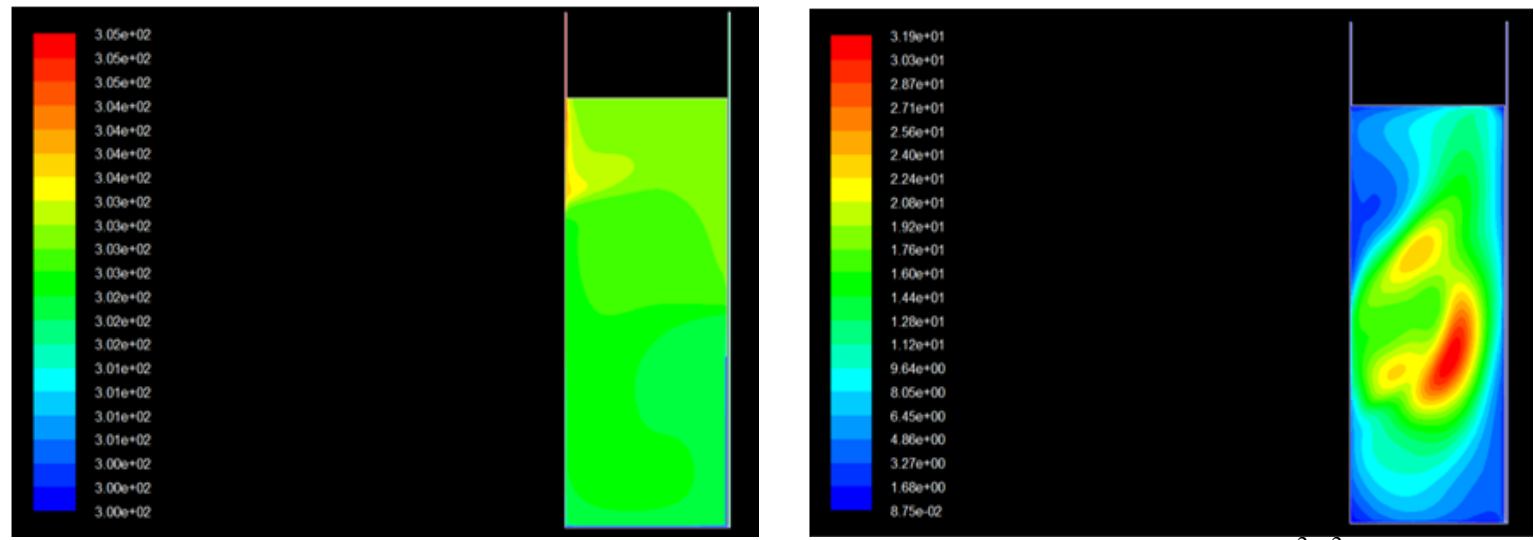

Fig.2 Counters of Static Temperature (k) [left], Counters of Turbulent Kinetic Energy $(\mathrm{k})\left(\mathrm{m}^{2} / \mathrm{s}^{2}\right)$ [right] Model: Standard k-epsilon, Ta: $32.3^{\circ} \mathrm{C}$, Ts: $26.6^{\circ} \mathrm{C}$
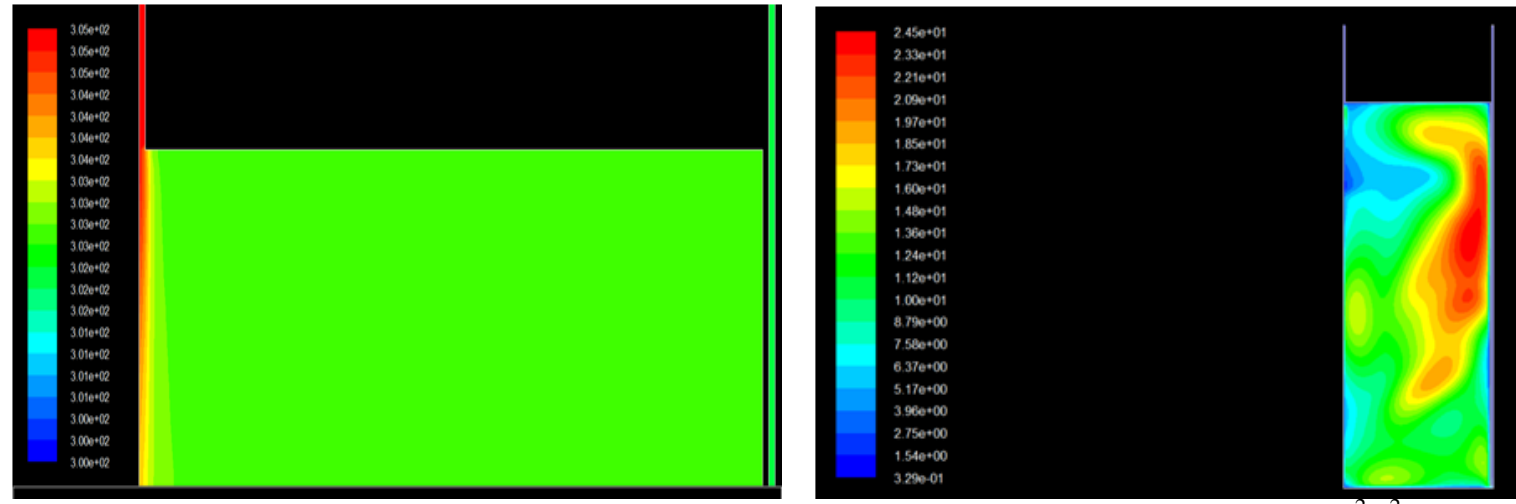

Fig.3 Counters of Static Temperature (k) [left], Counters of Turbulent Kinetic Energy $(\mathrm{k})\left(\mathrm{m}^{2} / \mathrm{s}^{2}\right)$ [right] Model: RNG k-epsilon, Ta: $32.3^{\circ} \mathrm{C}$, Ts: $26.6^{\circ} \mathrm{C}$
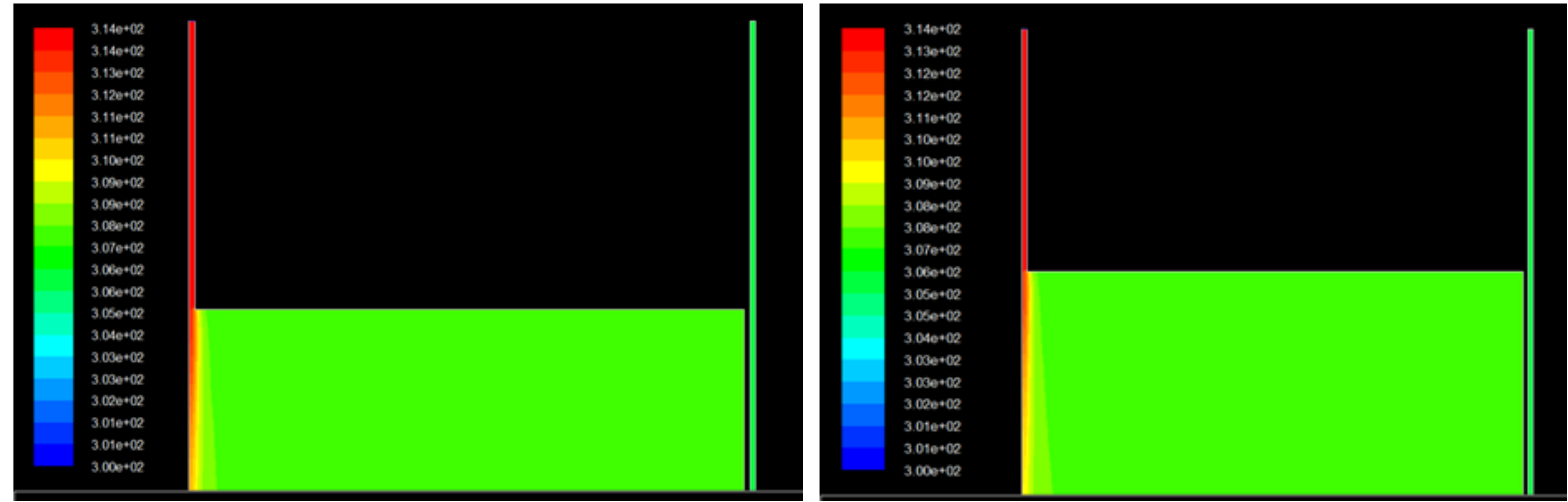

Fig.4 Counters of Static Temperature (k) Month: April (left) and May (right) Model: RNG k-epsilon, Ta: $32.3^{\circ} \mathrm{C}$, Ts: $26.6^{\circ} \mathrm{C}$

\section{CONCLUSION}

Earth-Air Heat Exchanger (EAHX) is considered to achieve a high efficiency and to improve their economical competitiveness. In this paper, tank were proposed in the conventional model and has been investigated using the computational fluid dynamics (CFD) code FLUENT to provide basic knowledge of the Air flow behaviour and to gather the first experience in the application of CFD codes to heat transfer in EarthAir Heat Exchanger (EAHX).A single pass earth-tank heat exchanger (ETHE) was performed to study its performance in cooling mode. ETHE is made of $0.5 \mathrm{~m}$ long $10 \mathrm{~cm}$ diameter $\mathrm{ms}$ pipe at inlet and $3.5 \mathrm{~m}$ long outlet tank with both wall thickness of $3 \mathrm{~mm}$. A $1 \mathrm{~m}^{2}$ area, $3 \mathrm{~m}$ deep was first excavated by a bucket excavator. ETHE is buried $3 \mathrm{~m}$ deep below surface. Air velocity in the pipe is $11 \mathrm{~m} / \mathrm{s}$. ETHE was able to reduce the temperature of hot ambient air by as much as $9.8^{\circ} \mathrm{C}$ in May. The basic soil temperature in May was $26.6^{\circ} \mathrm{C}$. Based on the results it can be stated that ETHE holds considerable promise as a means to cool air for a variety of applications such as the livestock buildings and greenhouses. 
In cooling modus, the heat exchanger is suitable for independent cooling of indoor air as well as for the supply of another cooling system. Possibilities for cooling are natural night ventilation, mechanical night ventilation and building mass activation. Three applications of cooling with an underground heat exchanger are "comfort cooling", "room cooling" and "supplement cooling". It was able to warm up the cold ambient air by a similar amount in the nights of January. The basic soil temperature in January was $24.2^{\circ} \mathrm{C}$.

Lower cooling energy costs, hygienically controlled air input (lower concentration of bacteria and fungi spores in the inlet air), possibility to reduce or avoid a conventional cooling system.

Typical cost indicators (relative to a conventional HVAC system)

Operating costs - lower

Operating maintenance costs - lower

Investment costs - higher

The underground heat exchanger can be combined with a conventional AC system, with a considerable reduction of its cooling load. Further, this technology can be combined with other passive cooling technologies such as night ventilation or can be used as a pre-stage to a heat pump.

\section{REFERENCES}

[1] Ajoy Debbarma, Down to Earth - For low Cooling by Earth Heat Exchangers in residential building, International Conference on Control, Communication, Computer Technology and Mechanical Engineering-2012

[2] Girja Sharan and Ratan Jadhav, Performance of Single Pass earth-Tube Heat Exchanger: An Experimental Study

[3] Miroslaw Zukowski1, Beata Sadowska2, Wieslaw Sarosiek3, assessment of the cooling potential of an earth-tube heat exchanger in residential buildings environmental engineering the 8th International Conference May 19-20, 2011, Vilnius, Lithuania Selected papers

[4] Al-Ajmi, F. et al. 2006. The cooling potential of earth-air heat exchangers for domestic buildings in a desert climate. Building and Environment, 41: 235-244.

[5] Sharan G. and Jadhav R. (2003). Soil temperature regime at Ahmadabad. Journal of Agricultural Engineering.

[6] Scott N.R.; Parsons R.A. and Kochler T.A. (1965). Analysis and performance of an earth-tube heat exchanger. ASAE paper no.65-840. St. Joseph, Michigan, ASAE.

[7] Spengler R. W. and Stombaugh D.P (1983). Optimization of earth-tube heat exchanger for winter ventilation of swine housing. Trans ASAE, pp $1186-1193$.

[8] Santamouris M., Mihalakaha G. Balaras C.A. Argirioua Asimakopoulos D. and Vallinaras M. (1995). Use of Buried pipes for energy conservation in cooling of agricultural greenhouse. Solar Energy. Vol. 35 PP 111-124

[9] Baxter, D.O. (1992) Energy exchange and related temperature of an earth-tube heat exchanger in heating mode. Trans ASAE, 35 (1): 275 - 285.

[10] Baxter, D.O. (1994). Energy exchange and related temperature of an earth-tube heat exchanger in cooling mode. Trans ASAE, 37 (1): 257 - 267.

[11] M. De Paepe, A. Janssens. Thermal-hydraulic design of earth-air heat exchanger. Energy and buildings 35 (2003) 389-397

[12] Vikas Bansal, Rohit Misra, Ghanshyam Das Agrawal, Jyotirmay Mathur. Performance analysis of earth-pipe-air heat exchanger for summer cooling. Energy and Buildings 42 (2010) 645-648 